\title{
"Spolu a spokojne“. Obrazy integrovanej spoločnosti v mestskom plánovaní
}

\author{
,Together and Contented". \\ Images of Integrated Society in Urban Planning
}

\author{
Slavomíra Ferenčuhová
}

\begin{abstract}
The article attempts to introduce urban planning as a particular field of interest within urban sociology and studies of urban change. In the introduction, urban planning is defined as an activity interconnecting production and use of expert knowledge, decision making on the level of local governance, and processes of creating representations of a city and - especially - its inhabitants. This approach is clarified in more detail when adopted to explain the role of these representations within contemporary urban planning. According to some authors, urban planning in Europe has been on the rise since 1980s, due to the attenuation of the nation state's role as guarantor and planner of cities' prosperity. Creating specific images of the 'place' and 'local identity' production become an important part of urban planning in this new context. Critical readings of case studies, as well as the proposed example of the city of Brno and the document Strategy for Brno, raise the question about the role representations of city inhabitants play in attempts to "integrate" urban society and in strenghtening the importance of the city as a structure of "identification" for inhabitants. Finally, the chances of cities competing with nation states as "levels" of identification are considered and questioned.
\end{abstract}

KEY WORDS Brno, „otherness“, post-socialist city, representation processes, social integration, strategical planning, urbanism and urban planning

\section{Úvod}

Európske mestá - ich fyzická podoba a život v nich - sa od počiatku modernej doby nepremieňajú samovol'ne, náhle a pred pasívnym pohl'adom obyvatel'ov a správcov. Ich štruktúra nesie stopy každodenných aktivít vel'kého počtu indivíduí a skupín sledujúcich vlastné záujmy, a zároveň je z nej možné vyčítat' vplyv obecných spoločenských trendov, ktoré d’aleko presahujú úroveň regiónu i štátu. Máloktorá zmena mestského prostredia sa však udeje bez vedomia (a často zásahu)

Sociální studia. Fakulta sociálních studií Masarykovy univerzity, 2/2006. S. 133-152. ISSN 1214-813X.

Táto štúdia vznikla s podporou Ministerstva školství, mládeže a tělovýchovy ČR - výzkumný záměr „Reprodukce a integrace společnosti“ (MSM002 1622408). Čast' práce bola prezentovaná v anglickom jazyku na IMISCOE B6 Workshop on Ethnic Diversity and Urban Public Space in Amsterdam, May 26-28, 2005, pod názvom „Place of Minorities in Contemporary Urban Planning in Post-Socialist Countries. Looking for ,Otherness“ in Strategy for Brno". 
odborníkov na riadenie mesta. Mestské plánovanie napriek tomu nie je príliš bežným predmetom záujmu výskumníkov poznávajúcich nedávny a súdobý vývoj českých miest a ich premeny. To, že sa jedná o predmet $\mathrm{v}$ českom prostredí zaujímavý, však dokazuje popis historicky sa meniacej roly i podoby plánovania rozvoja miest $\mathrm{v}$ období socializmu a po páde železnej opony, ktorý ponúka Jiří Musil (2002a,b), i jeho poznámka o dosial' chýbajúcom preskúmaní procesu tvorby i obsahu koncepcií rozvoja pred rokom 1989. Premeny organizácie lokálnej správy a nové úlohy „plánovania rozvoja“, pred ktorými sa ocitli české mestá v devätdesiatych rokoch, popisujú Balchin, Sýkora a Bull (1999), a o niektorých nových stratégiách uplatňovaných lokálnou správou a odborníkmi na rozvoj a zaist’ovanie prosperity miest a príliv zdrojov v prípade hlavného mesta Prahy píše Jana Temelová (2005). Na nasledujúcich stranách sa pokúsim predstavit’ mestské plánovanie ako predmet spoločenskovedného skúmania zameraného na poznávanie miest, ich premien a života ich obyvatel'ov. Predstavím pritom práce a prístupy, ktoré umožňujú nahliadat' na mestské plánovanie ako na expertnú činnost', ktorá je súčast'ou mestskej/lokálnej správy, a zároveň ako na proces utvárania hodnotovo podmienených reprezentácií mesta a jeho obyvatel'ov a ich plánovanej budúcnosti. Štúdie, z ktorých vychádzam, na jednej strane poukazujú na význam takéhoto poňatia mestského plánovania pre porozumenie jeho vplyvu na život mestských obyvatel'ov a na premeny mesta samotného. Na druhej strane ho tiež umožňujú vidiet' ako činnost', ktorá prostredníctvom svojich tvorcov odráža širšie spoločenské premeny a ukazuje vývoj súčasných miest a ich riadenia v kontexte lokálnom, národnom i globálnom. Poznatky vychádzajúce zo štúdií miest v západnej Európe a Spojených štátoch sa pokúsim vztiahnut' k situácii v druhom najväššom meste Českej republiky - Brne. Stručný popis hlavného súčasného plánovacieho dokumentu mesta Brna Strategie pro Brno a v ňom obsiahnutých obrazov jeho obyvatel'ov umožňuje nahliadnut' na podobu produktov dnešného plánovania. Najmä však upozorňuje na možnost' a potenciálny prínos prístupu, ktorý poznávanie mestského plánovania stredne vel'kých európskych „post-socialistických“ miest, akým je Brno, vzt’ahuje k širšiemu teoretickému i spoločenskému kontextu.

\section{Predmet štúdia: predstavy o budúcnosti mesta a jeho obyvatel'ov}

Plány rozvoja miest sú výsledkami práce expertov na ich usporiadavanie a riadenie. Mestské plánovanie sa čiastočne prekrýva s plánovaním územným, ktoré spočíva vo vymedzovaní budúceho využitia pozemkov; zároveň ho však presahuje. Jediné a jednotné vymedzenie súdobého pojmu mestské plánovanie pravdepodobne neexistuje. Ako ilustráciu l'ahko dostupnej a pomerne rozšírenej definície je možné uviest' tú, ktorú ponúka Wikipedia - otvorená on-line encyklopédia:

Urbánne či mestské plánovanie je disciplínou, ktorá sa zaoberá fyzickým, sociálnym a ekonomickým rozvojom metropolitných oblastí, obcí a (susedských) štvrtí, a to v rámci obecného plánovania využitia pozemkov (pôdy).

(Wikipedia, 22.9. 2006, preklad S. F.)

V odborných textoch zaoberajúcich sa mestským plánovaním, jeho históriou a teóriou, nájdeme $\mathrm{v}$ podstate obmeny tejto definície, doplnené o dôrazy na vybrané aspekty činnosti, ktoré autori a autorky považujú za podstatné. Nigel Taylor vo svojej knihe Urban Planning Theory since 1945 popisuje mestské plánovanie ako disciplínu zameranú primárne na plá- 
novanie (vy)stavaného prostredia. Pripomína zároveň, že zmeny mestského prostredia nie sú bez vplyvu na rurálne alebo na prírodné okolie, a preto je možné ako nad alternatívnym označením plánovania miest uvažovat' nad širším pojmom „environmentálne plánovanie“ (Taylor 2003: vi). Clara H. Greed (1999) zase upozorňuje na mnohost' rôznych mestských plánovaní, ktoré majú vlastné ,agendy“ i „priority“, ako napríklad „environmentálne plánovanie, mestský design, Euro-plánovanie, trhovo orientované plánovanie mestskej obnovy“, či sociálne plánovanie (Greed 1999: 3). Ako presne vymedzit’ a teoreticky uchopit' mestské plánovanie, je otázkou i pre autorov čítanky Readings in Planning Theory Susan S. Fainstein a Scotta Campbella (2003). Podl'a Fainstein a Campbella je často definované dvomi spôsobmi - na jednej strane stoja definície, ktoré vychádzajú z predmetu plánovania (tj. zo spôsobov využitia zastavaných i nezastavaných pozemkov), na druhej tie, ktoré za určujúcu charakteristiku urbánneho plánovania považujú proces rozhodovania (Campbell a Fainstein 2003: 2). Ako d’alej tvrdia, „hranice medzi činnost'ou plánovačov a iných odborníkov (projektantských firiem, architektov, mestských zastupitel'ov) nie sú ostré - plánovači robia i iné veci než plánovanie, a naopak ostatní odborníci sa na ňom môžu často podiel'at"“ (Campbell a Fainstein 2003: 2, preklad S. F.). Odpovedat' na otázku, kto je vlastne plánovač a čo robí, je zložité i preto, že urbánne plánovanie využíva kombinácie metód a prístupov, často vypožičaných od príbuzných disciplín. Väčšmi než jediná metóda ho preto vystihuje „zameranie na miesta a priestory; záväzok voči mestským obyvatel’om a pragmatická orientácia na profesionálnu prax" (Campbell a Fainstein 2003: 2).

Definíciu mestského plánovania môžeme rozšírit' o dôraz na jeho „ciele“ a s určitým zjednodušením ho chápat’ ako plánovanie spoločenských zmien, ku ktorým má napomôct' úprava priestoru (Fainstein a Fainstein, in Frisch 2002). Ovplyvňovanie života obyvatel’ov a vytváranie „dobrého“ mesta predstavuje ako ciel' súčasného plánovania Nigel Taylor (1999). Toto zameranie podl’a neho nebolo vždy súčast'ou mestského plánovania - aspoň nie vo Vel'kej Británii, ktorej prípad popisuje. Od tridsiatych rokov 20. storočia, ked' v Británii získalo vel'kú podporu, až do rokov šest'desiatych bolo totiž mestské plánovanie zamerané najmä na úpravu fyzického prostredia mesta. Chápané ako „prirodzené predíženie architektúry a/alebo stavebníctva“, nekládlo si príliš otvorene za ciel' ovplyvňovat' život obyvatel'ov. Taylor považuje zmenu jeho orientácie do značnej miery za reakciu na uvedomenie si dopadov necitlivého povojnového plánovania a za vyjadrenie snahy zmiernit' sociálne nerovnosti (Taylor 1999: 29-30).

Praktické zameranie plánovania a jeho orientácia na „akciu“ a nastol’ovanie zmeny určuje i otázky, ktoré si kladú jeho teoretici. Teória urbánneho plánovania by podl’a Taylora mala okrem iného odpovedat' na otázky, čím je charakteristické „vysoko kvalitné mestské prostredie“, za akých podmienok môžeme takéto prostredie vytvorit', a v prípade, že „samotné verejné mestské plánovanie je jednou z týchto podmienok, mala by pomáhat' zistit', akú úlohu môže zohrávat' v tvorbe lepšieho prostredia pre l'udský život“" (Taylor 2003: vii-viii). Riešenie podobných otázok teórii plánovania predkladá aj úvodná kapitola Susan S. Fainstein a Scotta Campbella k výberu základných textov v už vyššie zmienenej čítanke. Nasledovnú otázku uvádzajú hned' na prvej stránke ako ústrednú pre teoretické štúdium plánovania: Akú rolu môže plánovanie zohrávat'v utváraní dobrého mesta a regiónu v rámci obmedzení, ktoré kladie kapitalistická politická ekonomika a demokratický politický systém? (Campbell a Fainste- 
in 2003: 1; preklad a dôraz S. F.) Hoci, ako d’alej tvrdia, ich snahou nie je ponúknut' modelový postup pre plánovanie, i d’alšie otázky sa vzt’ahujú k podmienkam, ktoré ovplyvňujú možnosti plánovačov menit' a zlepšovat' prostredie mesta a život obyvatel'ov.

Na rozdiel od vyššie zmieneného tvrdenia Nigela Taylora, podla ktorého sa urbánne plánovanie až do šestdesiatych rokov 20. storočia príliš nezaujímalo o vlastný vplyv na život mestských obyvatel’ov, ponúka francúzska filozofka Françoise Choay (1965) vo svojom historickom výklade zrodu urbanizmu iný pohlad. Počiatky snáh premyslene, odborne, a najmä vedecky zasahovat' do usporiadania mesta ako celku siahajú v európskom prostredí do obdobia priemyslovej revolúcie. Urbanizmus ako veda či disciplína sa podla Françoise Choay sformoval v 19. storočí (Choay 1965: 8). Hoci plánovité usporiadavanie miest existovalo i v staroveku, a preto je korene moderného urbanizmu možné hl'adat' v tejto tradícii (vid' Vacková v tomto čísle), vznikajúca disciplína sa od predchádzajúcich „umení stavitel'stva“ líšila. Jej odlišnost' spočívala nielen $\mathrm{v}$ „,reflexívnom a kritickom charaktere“, ale najmä v „okázalej vedeckosti“" (Choay 1965: 8). Podl'a Françoise Choay viedli náhla premena podoby sídel, rast počtu obyvatel'ov a vnímaná chaotickost priemyselného mesta k rozvíjaniu dvoch spôsobov uvažovania o moderných mestách a živote v nich. Na jednej strane stáli pokusy o vedecký a nezaujatý popis prebiehajúcich javov. Druhý prístup zmeny zároveň sledoval i hodnotil a pokúšal sa formulovat' normy a odporúčania pre riadenie a fyzické usporiadanie miest, ktoré by bolo v súlade s predstavami o ideálnom živote spoločnosti a napomáhalo by ich realizácii. $\mathrm{V}$ rámci tohto prístupu mali prvotné úvahy o spôsoboch obnovenia poriadku podobu utopických vízií (Choay 1965: 10-15). Autormi týchto diel, ktoré Choay nazýva ,pre-urbanistickými“", boli generalisti 19. storočia (historici, ekonómovia a/alebo politici). Neskôr sformovaný urbanizmus - teoretický i praktický - sa naproti tomu stal záležitostou špecialistov, ktorí hl'adali oporu pre vlastné predstavy o rozvoji mesta v odborných poznatkoch. Realizácia predstáv o ideálnom rozvoji mesta sa postupne stávala „technickým problémom“ (Choay: 1965: 30).

Samotné slovo „urbanizmus“ sa zjavilo na počiatku 20. storočia a v bežnom jazyku dnes označuje ,inžinierske stavitel’stvo, vytváranie plánov miest, a zároveň mestské formy typické pre rozličné epochy“; definovaný ako „veda a teória l'udského stavitel'stva“, odkazuje tento pojem na predpokladanú vedeckú podloženost' ideí, ktoré stoja v základe rozhodovania o zásahoch do mestského usporiadania (Choay 1965: 8, 30). Tieto idey sú predmetom štúdia Françoise Choay v jej práci L'urbanisme: utopies et réalités (Urbanizmus: utópie a reality, 1965), i v neskoršom diele $L$ a règle et le modèle (Pravidlo a model, 1996). Choay sa väčšmi než o „konkrétny svet mesta“ a skutočne postavené budovy zaujíma o „priestor a mesto písané“, o ich prítomnost' v odborných textoch, ktoré náležia urbanizmu ako disciplíne (Choay: 1996: 15). Téma je zdanlivo odt’ažitá od reálneho mestského sveta a jeho problémov. Françoise Choay sa však naopak čuduje opomínaniu urbanistických textov tými, ktorí sa pokúšajú pochopit' priaznivé i negatívne (podl’a uhlu hodnotiaceho pohl'adu) zmeny mestského života. Pozornost' výskumníkov poznávajúcich život v meste zvyčajne neprit’ahujú texty - považujú ich totiž za nevinné a bez účinku. Podl’a Choay sú však javy, ktoré sociálni vedci pozorujú a označujú za problematické, často práve výsledkom snáh o realizáciu týchto „papierových predstáv“ v hmotnom prostredí mesta (Choay 1996: 15). Choay neupozorňuje na dopady akejsi nedostatočne reflexívnej či sociálne necitlivej tvrdej vedy. 
Urbanistické koncepcie, aj ked' formulované ako výsledky vedeckej práce, podl'a nej totiž naopak nie sú prosté hodnôt a predstáv o vhodnom rozvoji mesta a o živote jeho obyvatel'ov. Práve tie sa premietajú do dielčích rozhodnutí a zásahov do podoby mestských priestorov, a následne i do ich dopadov na mestský život. V závere svojej úvodnej eseje $\mathrm{k}$ antológii L'urbanisme: utopies et réalités Françoise Choay tvrdí:

Napriek predstieraniam teoretikov, mestské plánovanie nie je predmetom „tvrdej“ vedy. Dokonca samotná myšlienka vedeckého urbanizmu je jedným z mýtov industriálnej spoločnosti. V základoch akéhokolvvek návrhu na územné usporiadanie, za všetkými racionalizáciami a poznaním, ktoré sa tvári, akoby mu dodávalo pravdivost', sa skrývajú preferencie a systémy hodnôt.

(Choay 1965: 74)

Vo svojom texte používam spojenie mestské plánovanie, alebo tiež plánovanie mestského rozvoja, ako označenie aktivity zameranej na rozvoj, úpravu a určovanie využitia mestských priestorov. Súčasne však pod tento pojem spadá plánovanie zvyšovania životnej úrovne obyvatel'ov (prítomnost' služieb, rozvoj kultúrneho života a aktivít obyvatel'ov, efektívna mestská správa, kvalita životného prostredia), ekonomickej prosperity či technického zabezpečenia „chodu mesta“. Takéto chápanie pojmu umožňuje reflektovat' prepojenie priestorového plánovania a mestskej správy (procesu rozhodovania). Výsledkom mestského plánovania je totiž na jednej strane územný plán či jeho úpravy v grafickej podobe, na strane druhej sú to návrhy zmien týkajúce sa „života mesta a jeho obyvatel’ov“. Tieto dva druhy výsledkov sú neoddelitel'né; dokumenty, v ktorých sú formulované plány rozvoja mesta, sú akousi textovou podobou grafických plánov na úpravu a použitie jeho priestoru.

Práve od počiatkov ustanovovania disciplíny pretrvávajúce zameranie na prinášanie pozitívnych zmien do podoby miest a života ich obyvatel'ov a prepojenie technickej činnosti s utváraním obrazov „ideálneho“ mesta a jeho „ideálnych obyvatel’ov“ je dôvodom i môjho záujmu o texty dokumentujúce súčasné úvahy o rozvoji miest. Plány sú postavené na hodnotových predpokladoch a predstavách o tom, ako by mesto „malo“ vyzerat”. Dokumenty sprítomňujú obyvatel'ov mesta a ponúkajú predstavy o ich (súčasnom i budúcom) živote. Obyvatelia sú nielen adresátmi zmien, ale i ich potenciálnymi nositel'mi. V súčasnosti by poznámka F. Choay o necitlivosti bádatel'ov voči odborným textom o mestách pravdepodobne nezaznela. Od vydania knihy Davida Harveyho The Condition of Postmodernity sa analýza diskurzu - i diskurzu urbánnych plánovačov - stala bežnou súčast'ou poznávania mesta a jeho premien (Mele 2000: 628-629). Predmetom môjho záujmu sú teda texty dokumentujúce proces súčasného plánovania miest. Tieto dokumenty považujem za výpovede špecifických aktérov o meste, o jeho budúcnosti a o jeho obyvatel'och. Zároveň ich však chápem ako záznamy ideí a predstáv, ktoré sú súčast'ou poznania tvoriaceho pozadie pomerne širokého spektra (najmä administratívnych) rozhodnutí, prinášajúcich $\mathrm{v}$ konečnom dôsledku zmeny v rozvoji miest pozorované a skúmané i v rámci sociálnych vied. Súčasné plánovanie miest sa často výrazne líši od produkcie teoretických a vedeckých urbanistických textov, ktoré skúmala Françoise Choay. Má však blízko k praktickému urbanizmu - spája formuláciu predstáv o vhodnej budúcnosti mesta s rozhodovaním o „technických záležitostiach“ jeho fungovania, ako aj s otázkami verejnej správy. 
Dôvodov pre poznávanie plánovacieho procesu, dokumentov, ktoré sú jedným z jeho výsledkov a zároveň základom pre d’alšie rozhodovanie, a predstáv, presvedčení a obrazov, ktoré sú v nich obsiahnuté, je niekol'ko. Plánovanie je neoddelitel'nou súčast'ou „života“ súčasných (európskych) miest. Nie je len odbornou - technickou - disciplínou a praxou; je súčast’ou lokálneho rozhodovania a administratívnych procesov odohrávajúcich sa na úrovni miest. Preto sa pri popisovaní miest v rámci snáh o porozumenie ich premenám bez úvah o plánovaní nezaobídeme. Hodnoty a obrazy ideálneho rozvoja mesta, ktoré sa - viac alebo menej uvedomene - stávajú súčast’ou plánov, na jednej strane odrážajú širšie spoločenské, politické a ekonomické zmeny; v článku sa budem podrobnejšie venovat' premene plánovania európskych miest v posledných desat'ročiach 20. storočia. Plány sú ale zároveň záznamom predstáv o budúcom rozvoji mesta, vytvárané za účelom ich realizácie, a tak popri tom, ako širšie spoločenské zmeny odrážajú, napomáhajú ich „,vpisovaniu“ do mestských priestorov. Na nasledujúcich stránkach preto predstavím prístupy, ktoré umožňujú vidiet’ mestské plánovanie práve ako činnost', ktorá prepája využívanie expertného vedenia, politické a administrativne rozhodovanie a utváranie reprezentácií mesta a jeho obyvatelov. Kým v niektorých prípadoch je zdôrazňovaná legitimizačná funkcia procesov reprezentácie a tvorby obrazov mesta v plánovaní, ktoré znevýhodňuje určité skupiny obyvatel'ov, iné štúdie ukazujú plánovanie ako - viac alebo menej úspešne - reagujúce na meniace sa spoločenské podmienky, ktoré v podstate nemôže príliš ovplyvnit'. Následne po uvedení príkladov výskumov, ktoré uchopujú mestské plánovanie ako predmet spoločenskovedného skúmania v americkom či západoeurópskom prostredí, sa pokúsim zodpovedat' otázku o použitel'nosti tohto prístupu v prípade stredo- a východoeurópskych post-socialistických miest. Príklad Brna nepredstavuje snahu podrobne popísat' situáciu mestského plánovania v tomto meste. Je skôr uvedením otázok, ktoré môžu byt' kladené pri poznávaní súčasného plánovania stredne vel'kého európskeho „,post-socialistického“ mesta, a zároveň snahou poukázat' na uplatnitel'nost' teoretických prístupov a na využitel'nost' poznatkov získaných ich prostredníctvom v odlišnom prostredí. Príkladom a zúžením témy, ktorý pre tento ciel' volím, je vytváranie reprezentácií obyvatel’ov miest v mestskom plánovaní ako základnej súčasti tvorby vízie ,priaznivého rozvoja mesta“.

\section{Mestské plánovanie a rôznost' obyvatel'ov: Typový človek, ideálna komunita a diskurz mestského plánovania}

Úlohu reflektovat' a rešpektovat' rôznost' obyvatel'ov a ich potrieb prijímajú dnešní západní plánovači miest s určitou samozrejmost'ou. Ako píše Nigel Taylor (1999), slogan ,planning is for people ${ }^{\text {“1 }}$ sa stal v priebehu šest'desiatych rokov kvôli svojmu nadužívaniu temer ničnehovoriacim cliché (Taylor 1999: 30). Prístupov k sociálne citlivému plánovaniu, a/alebo k zohl'adňovaniu rozmanitosti života obyvatel'ov mesta, sa však v priebehu rokov objavilo mnoho, rovnako ako aj ich kritík, reformulácii či návrhov ich vylepšení. Varujúce popisy a analýzy dopadov nevhodných zásahov do mestských štruktúr na (skupiny) obyvatel’ov a ,skrytých mechanizmov vytvárajúcich a reprodukujúcich sociálne nerovnosti““ (Harvey 1973, podl’a Young 2003) boli

Plánovanie je pre l’udí. 
a dodnes sú nasledované odporúčaniami, ktoré sa liśia podl’a navrhovatel’om vyznávaných hodnôt a predstáv o ideálnom mestskom živote. ${ }^{2}$ Kritické analýzy plánovacej praxe a jej dopadov, ale i ideálov prítomných $\mathrm{v}$ jednotlivých prístupoch, sú doplńané analýzou samotného vzdelávania plánovačov ako procesu, ktorý reprodukuje nerovnosti na úrovni profesie, a tým napomáha $\mathrm{k}$ ich udržiavaniu či utváraniu v mestskom (i medzimestskom) svete (Thomas 2003).

Iris Marion Young (2003) popisuje z perspektívy kritiky liberálneho kapitalizmu nerovnosti života v meste ako následky nerovnej distribúcie tovaru a zdrojov, prístupu k rozhodovaniu či del'by práce a kultúrnych odlišností. Na ich reprodukcii sa však podla nej podiel'ajú aj municipality so svojimi rozhodovacími štruktúrami. Hoci je rozhodovacia moc predstavitel’ov obcí obmedzená zo strany štátu a korporácií, ich rozhodnutia $\mathrm{v}$ rámci územného plánovania nezostávajú bez dopadu (Young 2003: 351). Young preberá popis mechanizmov vytvárania a udržiavania nerovností od Davida Harveyho, ktorý medzi tie skryté radí prenikanie záujmov skupín (developerov, úradníkov) do rutinného procesu plánovania/rozhodovania, ktorý je samotný nastavený na opakované uprednostňovanie vel'kých a viditel'ných projektov. Ďalším z troch „skrytých mechanizmov" je rozhodovanie o (fyzickom) umiestnení projektu, ktorého častým efektom je popri priaznivých dopadoch uvedených v projekte i vymiestnenie lokálnych obyvatel’ov či obmedzenie ich prístupu k službám a/alebo vybaveniu. Adaptabilita jednotlivých skupín na zmenu v prostredí mesta je navyše rozličná, preto i ich prospech z nej nie je rovnaký a často sa zmenšuje práve podla ne/prítomnosti zdrojov pred zmenou (Harvey, podla Young 2003: 351-352). Young sa domnieva, že pokial' tieto mechanizmy popísané Davidom Harveyom zostanú skryté, budú mat' „politiky, ktoré si kladú za ciel' zlepšit' životné podmienky chudobných, marginalizovaných, či inak znevýhodnených obyvatel’ov miest, len malý účinok“ (Young 2003: 351).

Vytváranie politík integrácie sa stalo úlohou obcí a ich reprezentantov a tým i súčast’ou mestského plánovania najmä v posledných dvadsiatich rokoch 20. storočia (Le Galès 2002). Mestské plánovanie, ktoré by malo zabezpečit' priaznivý a (ekonomicky) prosperujúci vývoj mesta, pomáhat' riešit' diagnostikované sociálne problémy, ako aj vytvárat' identitu miesta a sprostredkúvat' „integráciu mestskej spoločnosti“", tak približne od začiatku osemdesiatych rokov zažíva opätovný rozmach. Plánovanie rozvoja mesta smerom k jeho (v rámci možností dosiahnutel'nej) ,ideálnej podobe“汭 je pritom neoddelitel'né od utvárania predstavy o jeho obyvatel'och/uživatel'och. Tento aspekt mestského plánovania (prípadne urbanizmu) zdôrazňujú viacerí autori - niektorí z nich sa snažia osvetlit' zakotvenie racionálnych expertných rozhodnutí v predstavách typového človeka či komunity (Choay 1965), iní sledujú, ako obraz obyvatel’ov mesta či štvrte napomáha ich legitimizácii (Mele 2000). V̌setky tieto práca napriek ich odlišnému zameraniu zakaždým otvárajú otázku, komu je urbanistami a mestskou správou plánované „ideálne“ mesto určené.

2 Kritiku komunitného plánovania založenú na podrobnej analýze hodnôt a presvedčení, z ktorých návrhy často nereflektovane vychádzajú, ponúka napríklad Iris M. Young (2003).

3 Prívlastok ,ideálny“ (vývoj, mesto, užívatel') vychádza z použitia tohto označenia autormi dokumentu Strategie pro Brno: „Strategické záměry a v detailnější podobě i Programové cíle určují žádoucí směry rozvoje města a svým pojetím respektují hranici mezi ideálním vývojem města a reálnými předpoklady“ (Strategie... 2002: 4). 
Od počiatkov svojho ustanovovania ako špecializovanej aktivity sa mestské plánovanie spája s utváraním predstavy typového človeka či ideálnej mestskej komunity. Françoise Choay v prehl'ade dejín urbanizmu odhal'uje existenciu dvoch modelov (,diskurzívnych konfigurácií", „typov priestorových projekcií“ či predstáv mesta budúcnosti), ktoré nazýva progresistickým a kulturalistickým. Progresistický (,,pokrokársky“) model je založený na predstavách pokroku a na „nádeji na budúcnost““. Podl'a Choay je u jeho predstavitel'ov, pre-urbanistov 18. a 19. storočia (Owen, Fourier, Richardson, Cabet alebo Proudhon), zjavná zdiel'aná predstava typového indivídua, typového človeka. Jeho potreby sú odvodzované od vedeckých poznatkov a sú „nezávislé na čase a priestore konkrétnych zosobnení“. Tento prístup si kládol za ciel' prispôsobit' hmotné prostredie človeku s jeho potrebami a so sklonmi, ktoré sú mu (ako model predpokladá) vrodené. ,Vel'ká otázka architektúry“ mala byt' vyriešená „racionálnou analýzou“, ktorá mala pomôct' vytvorit' univerzálne uplatnitel'né usporiadania (Choay 1965: 17). Kulturalistický model (s výrazne nostalgickými prvkami) opiera svoju kritiku rano priemyselného mesta o predstavu nie indivídua a jeho potrieb a vlastností, ale o charakter zoskupenia, ktoré vytvára mesto. „Indivíduum tu nie je zamenitel'né ako v prípade progresistického modelu.“ Má naopak svoje presne určené miesto, ktoré napomáha vytvorit’ a udržat',organickú jednotu“ (Choay 1965: 21). Oba modely podl'a Choay pretrvávajú i po ustanovení urbanizmu ako špecializovanej činnosti. Predstavy potrieb obyvatel'ov a užívatel'ov mesta, predpoklady ich činností, rovnako ako obraz priaznivej budúcnosti, určujú plány a koncepcie rozvoja miest dávno potom, čo prestali byt' označované ako utopické.

V rámci súčasných výskumov, ktoré venujú pozornost' obrazu užívatel'ov mesta utváranému v rámci mestského plánovania, je analýza diskurzu často vztiahnutá k otázke postavenia odlišných skupín obyvatel'ov v mestskej spoločnosti (Mele 2000, Frisch 2002). Práca Christophera Meleho dokladá význam spôsobov, akými sú mesto a jeho obyvatelia zobrazovaní v plánovacích dokumentoch, pre procesy ekonomického i politického rozhodovania a následne i pre premenu fyzickej podoby mesta a života obyvatel'ov. Mele sa pridáva k autorom skúmajúcim ,procesy, v ktorých rétorika, obrazy, symboly a reprezentácie [...] simultánne odrážajú a ovplyvňujú sociálne praktiky prebiehajúce v konkrétnych časových a priestorových rámcoch“ (Mele 2000: 628). Dôvodov, pre ktoré je dôležité zaoberat' sa diskurzívnou analýzou prevládajúcich expertných reprezentácií mesta, uvádza niekol'ko. Pôvodný predpoklad, ktorý je dosial' považovaný niektorými autormi za ideál, chápe obraz miesta za výsledok konsenzu jeho užívatel'ov o jeho význame, za produkt vytváraný v dlhom časovom období a za adekvátnu reprezentáciu miesta a jeho skutočne najvýznamnejších charakteristík. Podl'a Meleho však reprezentácie vznikajú ako výsledok komplexného procesu tvorby s nejednoznačným autorstvom. Ich vzt’ah k politickým a ekonomickým procesom spočíva v sile obrazov miesto nielen popisovat', ale zároveň jeho vybrané charakteristiky vysvetl'ovat', upevňovat' alebo naznačovat' ich želané zmeny. Reprezentácie sú zdrojom presvedčení o tom, čo je pre danú lokalitu vhodné a nevhodné, možné a nemožné, legitímne a nelegitímne, a tým formujú podklady pre súhlas verejnosti s určitými zmenami (Mele 2000: 630-631).

Význam urbanistického diskurzu pre procesy reštrukturalizácie mesta ilustruje Mele na štúdii návrhov na prestavbu ghetta na Lower East Side v New Yorku obývaného imigrantmi-robotníkmi v rokoch 1920 až 1930. Ked’že nepredpokladá priame spojenie medzi prevládajúcimi obrazmi mesta a procesmi jeho zmien, sústredí sa na diskurzívne praktiky aktérov 
(plánovačov, obchodníkov s realitami) presadzujúcich vlastné záujmy v oblasti reštrukturalizácie. Odhal'uje tri hlavné spôsoby tvorby a využívania dominantného obrazu mesta. Prvým z nich je ,použitie diskurzu na definovanie mestskej prestavby ako normálnej a prínosnej“ (Mele 2000: 632). V tomto prípade je vybraná lokalita označená za problematickú a riešenie jej problémov za nevyhnutné. Navrhované zmeny sa zdajú byt' tými najvhodnejšími a obyvatelia či užívatelia sú ochotní pristúpit' na náklady, ktoré zmena prinesie. Použitie obrazu, ktorý miesto ukazuje ako nositel'a sociálnych problémov, umožňuje prijatie navrhovaných zmien a, ako tvrdí Mele, „,neutralizuje nesúhlas verejnosti“ (Mele 2000: 632). Iným využitím reprezentácie mesta je podl’a autora ospravedlnenie procesu urbánnej reštrukturalizácie a zvlášt’ jej spoločenských následkov. Mele síce tieto dve použitia odlišuje, obe sa však týkajú získavania súhlasu s navrhovanými zmenami a ich následkami. Ciel’ tvorby a použitia obrazu mesta je v oboch prípadoch rovnaký - je ním legitimizácia činnosti aktérov zapojených do procesu mestského plánovania a prestavby.

To, že majú plánovači v skutočnosti presnejšiu predstavu ideálneho užívatel’a, sa prejavuje v tret'om spôsobe využívania diskurzu o meste $-\mathrm{v}$ tvorbe novej identity miesta. Prít'ažlivost' lokality pre ideálneho (investormi želaného) užívatel’a nie je daná jednoducho premenou jej fyzickej podoby. Pokial' bolo miesto považované za nebezpečné, nestačí premenit' jeho podobu. Je nutné zmenit' i jeho históriu a príbehy (Mele 2000: 632-633). Tie nové sú formulované tak, aby zvlášt’ prit’ahovali želaného konzumenta lokality. Obyvatelia, ktorí do obrazu nezapadajú, sú symbolicky vylúčení zo skupiny očakávaných užívatel’ov. V prípade, že sú súčasnými obyvatel'mi, vedie ich vylúčenie z obrazu často i k reálnemu vylúčeniu z lokality - po zmene cien nehnutel’ností a/alebo výšky nájmov väššinou z ekonomických dôvodov. ${ }^{4}$

Problematiku vylúčenia skupiny obyvatel'ov nie z konkrétnych miest, ale už zo samotných predstáv miesta v procese jeho plánovania, otvára výskum Michaela Frischa (2002). Koncept urbánneho plánovania podl'a neho vznikal v rovnakom čase, $\mathrm{v}$ akom boli formulované moderné koncepcie sexuálnej orientácie. S ciel'om objasnit' vzt’ah užívania mesta gay a lesbickými komunitami k urbánnemu plánovaniu Frisch analyzuje kl'účové texty významných urbanistov a ukazuje, ako urbánne plánovanie pracuje s nespochybňovaným predpokladom heterosexuality obyvatel’ov. Plánovači zo začiatku 20. storočia (cituje autorov Chicagského plánu Bennetta a Burnhama) považovali plánovanie za prostriedok dosahovania tých najlepších možných životných podmienok pre všetkých obyvatel'ov mesta. Pri bližšom skúmaní však zistíme, že medzi všetkými niekto chýba. Frischov výskum sleduje praktiky používané, viac alebo menej otvorene, urbánnymi plánovačmi na vylúčenie spôsobov využívania priestoru gay a lesbickými komunitami, a naopak na presadenie spôsobu užívania priestoru typického pre heterosexuálnu väčšinu. Tento spôsob (rodinný život v oddelených domoch, obmedzené „poriadkumilovné“ využívanie verejných priestorov) je presadzovaný ako norma. Reprodukcia štruktúr heterosexuálnej dominácie činí podl'a Frischa z plánovania heterosexistický projekt - pravidlá a postupy plánovania sú založené na heterosexuálnych konštrukciách rodiny, práce a komunitného života a prispievajú $\mathrm{k}$ ich reprodukcii.

$4 \quad$ Symbolické „odsúvanie“ aktivít skupín menšinových obyvatel’ov, i „,vymiestňovanie“ pomocou zmeny účelu miesta/lokality, popisuje v prípade mesta Solún Panos Hatziprokopiu (2004). 
Obe štúdie sú príkladom skúmania tvorby obrazu obyvatel'ov mesta v rámci mestského plánovania a napriek odlišnej formulácii problému zdiel'ajú dva základné predpoklady. Autori v prvom rade uznávajú dôležitost' prítomnosti obrazu mesta a jeho obyvatel'ov v mestskom plánovaní. Obraz však nepoznávajú samotný, ale v jeho prepojení s ,realitou“ priestoru a života odlišných štvrtí či skupín. Prvý výskum ukazuje použitie reprezentácií na dosahovanie špecifických ciel'ov plánovačov a investorov, teda využitie možného dopadu obrazu (a jeho premeny) na „skutočný“ život mesta. Michael Frisch sa zase v závere článku dostáva k formulácii odporúčaní pre ,inkluzívne“ plánovanie, ktoré odstráni symbolické vylúčenie určitého typu obyvatel'ov, a požaduje ich včlenenie do obrazu mesta, kam dosial' nepatrili. Druhým bodom, kde sa prístupy približujú, je predpoklad existencie ohrozenej skupiny obyvatel'ov, ktorú vymedzujú zvýznamnením jedinej charakteristiky. V prvom prípade sa jedná o obyvatel'ov lokality/štvrte, v druhom prípade o obyvatel'ov s homosexuálnou orientáciou. Zvolená významná charakteristika obom autorom stačí k zahrnutiu všetkých, ktorí a ktoré ju zdiel'ajú, do jednej kategórie. Jedinci pritom podl'a autorov zdiel'ajú okrem tej vymedzenej a pomenovanej i d'alšie zhodné charakteristiky či potreby, ktoré by mali byt' v plánovaní reflektované.

Voči obom týmto východiskám chcem vymedzit' vlastnú pozíciu. Zdôvodňovanie skúmania obrazu mesta, ktorý tvoria mestskí plánovači, má často podobu poukázania na jeho skutočný či potenciálny dopad na „realitu“ mestského života. V prípade, ak skúmanie nedospeje $\mathrm{k}$ popisu takéhoto dopadu, alebo aspoň k predpokladaným následkom či návrhom na to, ako sa mu vyhnút', je považované za irelevantné, nehodné pozornosti a odtrhnuté od života s jeho problémami. Poznávanie samotného pohl'adu aktérov na mesto a jeho obyvatel'ov, hl'adanie významov a výpovedí o meste, je obvykle považované za prijatel'ný ciel' skúmania, iba pokial' je vypovedajúcim aktérom „obyčajný“, „bežný“ obyvatel’ či užívatel’ prostredia (napríklad výskumy Koskela 1999, Reynaud 2004).

Autori koncepcií rozvoja mesta a mestských plánov ale nestoja mimo život mesta, naopak, sú jeho súčast’ou, sú aktérmi, ktorí síce možno nie sú „,bežní“, ale zato majú moc svoj pohl'ad presadzovat'. Dokumenty mestského plánovania sú výpoved'ou týchto aktérov - v role reprezentantov mesta a špecialistov na jeho rozvoj či správu - o tom, ako mesto vnímajú a čo považujú za priaznivé smerovanie jeho vývoja. Hl'adanie spojitosti medzi obrazom a realitou, ktorý ponúka rovnako Frisch a Mele, je preto vel'mi vhodné doplnit' hl'adaním vnútorných spojitostí a prípadných inkonzistencií v samotných obrazoch ideálneho mesta; poznávanie vplyvu mestského plánovania na situáciu menšinových skupín v meste zase poznávaním obrazu mestskej spoločnosti ako celku, ako integrovanej spoločnosti, ktorú si autori plánov predstavujú ako prítomnú v súčasnom i budúcom meste. Okrem sústredenia sa na akty vylučovania určitých kategórií obyvatel'ov z obrazu mesta, je možné venovat' pozornost' naopak spôsobom spritomňovania rozličností medzi obyvatel'mi v obraze mesta ako celku, na cesty ich integrácie do tohto obrazu, a na momenty, ked' je odlišnost' obyvatel'ov zvýznamnená a ked' zohráva rolu v určovaní spôsobu, akým obyvatelia vstúpia do urbanistického plánu. Hladanie spôsobov, akým odlišnosti a skupiny vznikajú v samotnom obraze, navrhujem nie ako alternatívu sledovania ne/prítomnosti reálnych skupín $\mathrm{v}$ reprezentácii mesta, ale ako (základnú) súčast' poznávania tvorby a používania diskurzu plánovania ako expertnej i administratívnej činnosti. Skúmanie mestského plánovania v zmysle expertmi a mestskými reprezentantmi schval'ovaného obrazu integrovanej spoločnosti chcem preto navrhnút' ako 
perspektívu, ktorá dopíňa štúdie zamerané na poznávanie plánovania ako procesu reprezentácie mesta a jeho obyvatel'ov. K tomuto ciel'u napomáhajú súčasné analýzy podoby mestského plánovania a mestskej správy obecne, ktoré ponúka Patrick Le Galès či Yuri Kazepov a ktoré predstavím nižšie. Ako ilustrácia navrhovanej perspektívy poslúži krátky pohl’ad na hlavný plánovací dokument mesta Brna. Ale skôr než k nemu obrátime pozornost', položíme si otázku o prípadných špecifikách plánovania európskych „post-socialistických“ miest.

\section{Aplikovatel'nost' východísk na prípad plánovania post-socialistického mesta}

Dosial' zmienené koncepcie i postrehy o súčasnom mestskom plánovaní, jeho „moci zobrazovat"“ a vzt'ahu plánovania $\mathrm{k}$ životu obyvatel’ov, vychádzajú zo situácie západoeurópskych či amerických miest. Je ale možné rovnako definovat' mestské plánovanie v prípade miest strednej a východnej Európy? A je možné klást' v oboch prípadoch rovnaké otázky o podobe utvárania reprezentácií mesta, jeho obyvatel’ov a ich ,ideálnej budúcnosti“? Otázku, čo sa dialo s mestami v krajinách strednej a východnej Európy, v ktorých vládol socialistický režim, a aký bol ich vývoj v porovnaní s vývojom ostatných európskych miest, si v devätdesiatych rokoch položili viacerí sociálni vedci. Zmapovanie rozdielov medzi mestami nachádzajúcimi sa na jednej i druhej strane spadnutej železnej opony je záležitost'ou historickej analýzy, mnohí autori sa však zároveň vo svojom skúmaní snažili postrehnút' najnovšie trendy vo vývoji post-socialistických európskych miest. U viacerých (Häussermann [1996], ale i Musil [2002a]) zaznieva presvedčenie, podl'a ktorého celkový vývoj post-socialistických miest je a bude (alebo by mal byt') obnovovaním „prirodzeného poriadku“ a smerovania, nadviazaním na predsocialistické obdobie a priblížením $\mathrm{k}$ situácii západoeurópskych miest. Jedným z významných rozdielov pozorovatel'ných medzi kapitalistickým a socialistickým európskym mestom - a následne i mestom post-socialistickým - je však každopádne práve odlišná rola plánovania rozvoja pred rokom 1989.

Podl’a Hartmuta Häussermanna (1996) sa plánovanie miest v krajinách s kapitalistickým režimom v druhej polovici 20. storočia vyznačovalo väčšou vol'nost’ou a hl'adaním kompromisov medzi verejnými a súkromnými záujmami. Pôsobenie plánovačov (a tým pádom štátu) na skutočné užívanie pôdy $\mathrm{v}$ mestách bolo teda $\mathrm{v}$ podstate vždy obmedzené. To neplatilo pre „socialistické mestá“ - centrálna koordinácia, absencia investícií zo strany súkromníkov (a absencia súkromných vlastníkov nehnutel'ností a pôdy), ako aj rigídne hierarchické rozhodovanie, poskytovali obrovský priestor pre plánovanie zo strany štátu. Podla Häussermanna bolo v tomto období a pri tomto nastavení skutočne možné realizovat' vo fyzickom priestore miest celé teórie a koncepcie, pričom finálnu podobu prevedení určovali štátni úradníci.

Plánovanie radí Häussermann medzi základné „riadiace princípy“ (guiding principles) socialistických miest; pokusy vytvárat' ideálne mestá a definovat' princípy výstavby i symboliky prisudzuje $\mathrm{v}$ druhej polovici 20. storočia $\mathrm{v}$ podstate výlučne socialistickému urbanizmu. Základné znaky, ktoré vyplývajú z týchto plánovacích koncepcií, zahŕňajú napríklad štruktúru mesta: dôraz kladený na centrum mesta, na zhromažd’ovaciu a oslavnú funkciu námestia a symbolickú hodnotu nových a honosných budov v centre. Opakovanie týchto vzorcov v jednotlivých mestách pravdepodobne súvisí s jedným z ciel’ov urbánneho plánovania - snahou o dosiahnutie homogénneho socialistického spôsobu mestského života. 
Podobne i Jiří Musil pri popise vývoja miest v socialistickom Československu upozorňuje na významnú rolu plánovania, avšak sústredí sa na dopady plánovania centrálneho. Na rozdiel od Häussermanna, ktorý zdôrazňuje moc plánovačov určovat' podobu jednotlivých miest, popisuje Musil vplyv celkového riadenia ekonomiky na vývoj a postavenie miest v krajine. Podobne ako Häussermann však zmieňuje tendenciu socialistických plánovačov presadzovat' predpoklady vhodného a rovného bývania a služieb, často navrhovaného na základe presvedčenia o správnosti a vhodnosti „technologického zabezpečovania potrieb socialistického človeka“. Pri formulovaní „koncepcií osídlenia“ a „koncepcií urbanizácie“ sa pritom plánovači podla Musila pravdepodobne často inšpirovali koncepciami formulovanými v „západnej“ Európe, ktoré prispôsobovali svojím potrebám (Musil 2002b: 260).

Zmena, ktorá zasahuje plánovanie na úrovni jednotlivých sídel po roku 1989, podl’a neho spočíva v presune kompetencií z centrálnej - štátnej - administratívy na lokálnu samosprávu. „Odstránenie tuhého centralizmu v správe“, „,návrat k demokratickým formám správy a regionalizmu“, k „plánovaniu miest, ktoré je konformné s trhom“, k „hodnotovému synkretizmu a k hodnotovej pluralite v politickej a ideovej sfére“ (Musil 2002a: 299), sú zmeny, ktoré sa dotýkajú i vývoja post-socialistických miest. V celkovom zhrnutí však Musil zdôrazñuje jedno:

Vliv státních, politických, plánovacích a administrativních rozhodnutí na osudy jednotlivých měst je nahrazován působením ekonomických mechanizmů, politika se stává v tomto ohledu slabším elementem, ekonomie silnějším.

(Musil 2002a: 313)

Otázka, nakol'ko je tento odhad presný a potvrdený v nasledujúcom období, však zostáva otvorená. Ako píšu Balchin, Sýkora a Bull a ako upozorňuje i Musil, bolo to práve ekonomické plánovanie a podriad’ovanie mestského a regionálneho rozvoja ekonomickým rozhodnutiam, ktoré vymedzovalo rozvoj sídel (Balchin, Sýkora a Bull 1999: 161). Zmeny, ktoré zmieňujú Musil i Häussermann, zrejme poukazujú na prechod od centrálneho riadenia k väčšej slobode rozhodovania $\mathrm{v}$ post-socialistických európskych mestách. U Musila dokonca nájdeme náznaky očakávania návratu k akémusi „prirodzenému“ a „správnemu“ vývoju miest, oslobodenie od ideológie, uvol’nenie administratívnych obmedzení, riadenie na nižšej úrovni správy, ktorú pravdepodobne považuje za bližšiu životu v lokalite, a preto lepšie vyhovujúcu miestnym podmienkam.

V prípade socialistického plánovania sa pomerne l'ahko prijíma predstava ideologickosti prítomnej v plánovaní miest, vnucovania modelov chovania a predpisovania potrieb obyvatel'ov. Práve tento rozmer mestského plánovania bol podla Musila i Häussermanna špecifický pre „socialistické“ mestské plánovanie a mal po roku 1989 v podstate vymiznút'. Vyššie zmienené teórie i prípadové štúdie však poukazujú na hodnotovú podmienenost' vytvárania koncepcií rozvoja a na prítomnost' predstáv ideálneho mesta a jeho obyvatel'ov i v „kapitalistických“ európskych a amerických mestách. Je teda možné domnievat' sa, že zmena, ku ktorej v plánovaní miest v post-socialistických krajinách došlo, nemala podobu vymiznutia predstáv ideálneho mesta a ideálneho užívatel'a, ale skôr ich premeny. Formulovanie koncepcií mestského rozvoja prešlo v Českej republike po reforme správy v roku 1990 do kompetencie miest samotných (Balchin, Sýkora a Bull 1999). S úlohou plánovat' rozvoj a zabezpečovat' vlastnú prosperitu, ako aj riešit' vlastné sociálne problémy, pred ktorú boli v priebehu osemdesiatych 
rokov postavené samosprávy $\mathrm{v}$ západoeurópskych mestách, sa české mestá teda vyrovnávajú od rokov devät'desiatych. Spôsoby rozhodovania o rozvoji ako aj stratégie zabezpečovania prílivu zdrojov, a tým záruky prosperity a pokrytia potrieb mesta, sa v západo- a stredoeurópskych krajinách postupne stále viac približujú - často i vd’aka preberaniu „západných vzorov“ a procesu „učenia sa“ zavedeným postupom na strane stredoeurópskych samospráv. Strategické plánovanie síce prichádza do Čiech s určitým meškaním oproti rozmachu v západnej Európe, na prelome tisícročia však formuluje svoj strategický plán Praha a v roku 2002 má i Brno svoju Strategii - plán rozvoja mesta, ktorý je podobný plánom vznikajúcim v ostatných európskych krajinách, a v ňom obraz „dobrého života“ v meste.

\section{Ideálne Brno a jeho obyvatelia}

„Strategie pro Brno postihuje dlouhodobé aspekty rozvoje města, které vytvářejí jeho identitu a vnější viditelnost“" (Strategie... 2002: 3). Autori a autorky dokumentu tvrdia:

Průmětem vybraných rozvojových priorit do fyzického prostoru města je územní plán. Strategie pro Brno je tedy rámcovým společenským zadáním územního plánu, definujícím žádoucí socio-ekonomický rozvoj města.

(Strategie... 2002: 3)

V tomto tvrdení zaznieva predpoklad, podl'a ktorého by úprava administratívne vymedzeného priestoru mesta $\mathrm{v}$ súlade s územným plánom mala napomôct' realizácii slovne formulovaných „priorít rozvoja“. Tak ako podl'a definície prijatej pre tento text, vychádza i v prípade Brna mestské plánovanie prepájajúce tvorbu vízií a stratégií rozvoja s územným plánovaním z predpokladu, podl’a ktorého je jeho úlohou ovplyvňovat' sociálne procesy odohrávajúce sa $v$ meste mimo iné prostredníctvom úpravy fyzického priestoru a pravidiel jeho využitia. Dokument je rozdelený do piatich častí. V úvode predstavuje sám seba a okolnosti svojho vzniku. Druhá a tretia čast' sú venované popisu súčasného stavu a analýze silných a slabých stránok mesta. Štvrtá kapitola je formuláciou „strategických vízii “, piata je ich prekladom do konkrétnejších „strategických zámerov“ a dielčích „programových ciel’ov“. V oboch hlavných častiach dokumentu (analýza a vízie) operujú autori so štyrmi adjektívami pripájanými k slovu mesto - perspektívne mesto, prosperujúce mesto, mesto fungujúce a obývatel’né. K týmto jednoslovným charakteristikám postupne pridávajú konkrétnejšie predstavy ich naplnenia - súčasného i budúceho - pre prípad Brna. S prívlastkom perspektívne sa tak napríklad spája posilnenie významu Brna $\mathrm{v}$ európskom kontexte a v kontexte regiónu a vytvorenie lokálnej identity a image mesta. Prosperujúce mesto je typické prítomnostou technologicky vyspelých výrobných odvetví, vzdelaného obyvatel'stva, široko štruktúrovaného trhu práce a plnením roly univerzitného centra. Fungujúce mesto charakterizuje priestorová vyváženost' územia vo vzt’ahu $\mathrm{k}$ sociálnym a ekonomickým funkciám a zvládnutá doprava i technická infraštruktúra. Konečne $\mathrm{v}$ obývatelnom meste je dostupné kvalitné bývanie pre všetky vrstvy obyvatel'stva, mesto je bezpečné a „aktívne predchádza vzniku fyzicky a sociálne degradovaných oblastí“. Zabezpečuje plnohodnotný život pre všetkých obyvatel’ov, vrátane zdravotne znevýhodnených, je centrom kultúrnych, športových a vol’nočasových aktivít obyvatel'stva (Strategie... 2002: 66). 
V rámci tohto obrazu sa objavuje priemerný (bežný) „každý občan“, obyvatel’ mesta Brna. Jeho základné potreby sú zhrnuté do štyroch (šiestich) bodov:

Pro spokojený život každého občana jsou nejpodstatnější čtyři základní věci - dobré zdraví, št’astný rodinný život, přiměřené životní šance a pracovní uspokojení. Tyto čtyři oblasti zahrnují téměř vše, co člověk potřebuje k životu, a zároveň jsou to věci, které nelze trvale udržet jenom z iniciativy jednotlivce, ale musí se o ně ve větší či menší míře postarat stát prostřednictvím svých institucí a v přenesené působnosti pak město. [...]

K těmto čtyřem nejzákladnějším oblastem života člověka [...] je třeba ještě přidat zajištění bezpečnosti občanů a zajištění fungování města jako uceleného systému.

(Strategie... 2002: 46)

„Definícia“ obyvatel’a je založená na vymedzení základných potrieb a odkazom na životné potreby sa pokúša zahrnút' skutočne všetkých obyvatel'ov. Jej normatívny charakter a odkaz na „l'udskú podstatu“ pripomína pojem typový človek (homme-type), ktorý zaviedla Françoise Choay na označenie predstavy človeka vytvorenej na základe vedecky podloženého poznania univerzálnych l’udských potrieb pre-urbanistickými autormi vízií mestského rozvoja. Autori strategického plánu rozvoja mesta Brna však medzi obyvatel'mi, ktorí sú v zásade všetci definovaní vymedzenými potrebami (,každý občan“ potrebuje pre spokojný život to isté), d’alej rozlišujú. Okrem zmieneného „občana“ sa v Brne objavujú i obrazy skupín, ktoré sú odlíšitel’né na základe d'alších charakteristík, iných, než sú základné potreby. Popri výpočte rozličných národností obyvatel'ov žijúcich v Brne sa vymedzenie odlíšitel'ných skupín objavuje napríklad v súvislosti so sociálnym zabezpečením, bezpečnost'ou v meste, alebo charakterom kultúrneho života. Nasledujúce príklady postupne ilustrujú tieto tri zmienené kontexty:

Systém sociální pomoci v Brně musí reagovat na řadu ekonomických, demografických a sociálních změn a celospolečenských trendi̊. Vedle tradičních cílových skupin (senioři, zdravotně postižení občané, děti a mládež) narůstá v posledních letech také potřeba péče o další marginalizované skupiny obyvatelstva, které jsou ohroženy sociální exkluzí (bezdomovci, sociálně nepřizpůsobiví, matky $\mathrm{s}$ dětmi v tísni, migranti, národnostní menšiny, Romové, drogově závislí, mládež s výchovnými problémy).

(Strategie... 2002: 44)

Výchozím předpokladem je, že rozvíjet se může jen bezpečné město, tj. takové, ve kterém se nikdo necítí ohrožen na zdraví, životě a na majetku. [...] V roce 1996 byla provedena komplexní analýza bezpečnostní situace v městě Brně. Na základě analýzy byly pro období 2. poloviny 90 . let stanoveny hlavní bezpečnostní problémy města Brna, mezi kterými čelná místa zaujímají problematika trestné činnosti dětí a mládeže, obavy obyvatel z romské menšiny a dopravně bezpečnostní komplex problematiky města.

(Strategie... 2002: 48)

Specifikem Brna je, že základy brněnské kultury byly formovány multietnickou různorodostí města (působili zde Češi, Rakušané, Němci, Židé, v mladší historii např. Řekové či Bulhaři aj.).

(Strategie... 2002: 50) 
Vo všetkých troch úryvkoch sú zmienené zvláštne kategórie obyvatel'ov, ktoré ich ako nositel'ov akýchsi prídavných charakteristík v rozličných kontextoch odlišujú od celkom „bežných občanov“. V prvom prípade sú to tí obyvatelia, o ktorých sa predpokladá, že bud' vyžadujú alebo budú vyžadovat' zvláštnu pozornost' v rámci systému sociálnej starostlivosti. Ciel'ové skupiny sociálnej pomoci sú podl'a úryvku nasledovné: seniori, deti a mládež ako kategórie definované na základe fázy životného behu a vzt'ahu k trhu práce, zdravotne postihnutí občania ako kategória zdravotne znevýhodnených, bezdomovci a matky s det'mi v tiesni ako sociálne znevýhodnení, drogovo závislí, mládež s výchovnými problémami, sociálne neprispôsobiví ako nositelia „spoločenského problému“ v podobe sociálnej odchýlky, a nakoniec Rómovia, národnostné menšiny a imigranti. Sú to pravdepodobne zvláštne potreby prisudzované l'ud’om v určitej životnej situácii, prípadne obyvatel'om mesta so zdravotným či sociálnym znevýhodnením, ktoré z nich činia potenciálnych adresátov sociálnej pomoci. Prítomnost' kategórií Rómovia, národnostné menšiny a migranti medzi skupinami možných príjemcov je v tomto kontexte do určitej miery mätúca, pretože bez d’alšieho vysvetlenia stavia (dobrovol'ne deklarovanú?) príslušnost' k národnostnej menšine, či skutočnost' presunu z jednej krajiny do druhej, na úroveň problému - jednotlivca či skupiny.

Podstatné však nie je hl'adanie dôvodov či „skutočného“ významu vyčlenenia kategórií potenciálnych príjemcov sociálnej pomoci, ktoré by iste mohli byt' z pohl'adu tvorcov dokumentu objasnené. Zaujímavé je sledovat' sprítomňovanie inakosti obyvatel'ov, odlišnosti od „bežného občana“, $v$ jednotlivých kontextoch. V druhom úryvku je zmienená rómska menšina v súvislosti s bezpečnost'ou obyvatel'ov ako stojaca proti dominantnej skupine. V tomto odstavci slovné spojenie „obavy obyvatel z romské menšiny“ a priori vylučuje rómsku menšinu z kategórie obyvatel’ov, a to napriek tomu, že jediná definícia obyvatela, ktorú dokument ponúka, je postavená na popise potrieb. Tie síce vylučujú osoby rozhodnuté nežit' rodinným životom, či nehl'adat' uspokojenie v práci, ale nezmieňujú príslušnost' $\mathrm{k}$ akýmkol'vek menšinám. V súvislosti s bezpečnost'ou sa inakost' zjavuje na ohrozujúcej strane. Podl'a poslednej citácie je (historická) prítomnost’ „etnických skupín“ v Brne zdrojom zvláštneho charakteru brnianskeho kultúrneho života. Opät' nevymedzený pojem etnicity v citovanom odstavci odkazuje na predpokladanú „kultúrnu odlišnost"“ menovaných skupín, vol'ba ktorých je nepriehl'adná a jej dôvody málo zrejmé. Inakost' tu jednoducho získava podobu kultúrnej inakosti viazanej na národnost’ či náboženstvo.

\section{Mestské plánovanie ako stratégia integrácie}

Uvedené príklady obrazov mesta, ako aj „ideálneho obyvatel'a“ a jeho „trochu iných“ spoluobčanov, je len vel’mi stručným naznačením kontúr reprezentácie Brna a jeho obyvatel’ov ponúknutej v dokumente Strategie pro Brno. Práve ich prostredníctvom však vzniká celkový obraz súčasného stavu mesta, vízie jeho priaznivej budúcnosti i návrhy ich realizácie. Tie majú okrem iného za ciel' posilnit' obraz mesta ako samostatnej jednotky a ako úrovne identifikácie pre jeho (rôznych) obyvatel'ov. Podl'a Patricka Le Galèsa (2002) ožíva mestské plánovanie $\mathrm{v}$ západnej Európe $\mathrm{v}$ posledných desat’ročiach najmä v podobe plánovania strategického, ktorého je brnianska stratégia príkladným výstupom. Tvorba tohto typu dokumentu je súčast'ou urbánnej správnej aktivity a zahíňa dva aspekty - aspekt identity a prognostiky 
(popis súčasnej situácie mesta, „odhalenie“ jeho silných a slabých stránok, reflexia ekonomickej situácie a medzinárodného postavenia a možnosti úpravy jeho image) a aspekt operačný - návrhy jedného či viacerých projektov transformácie mesta a/alebo ekonomických aktivít zapájajúcich lokálnych aktérov i lokálne zdroje. (Pinson 2002, podl’a Le Galès 2002: 224)

Tvorbou strategických plánov administratíva a mestské elity reagujú na meniacu sa rolu národného štátu vo vzt’ahu k mestám (Le Galès 2002). V rámci akademickej debaty o premenách mestského riadenia na konci 20. storočia proti sebe vystupujú odlišné názory na posun v pôsobení štátu na mestá a ich správu. Le Galès tvrdí, že vplyv štátu oslabuje pod tlakom globalizačných trendov, čo mestám neprináša len väčšiu slobodu rozhodovania, ale tiež zníženie štátnej garancie prosperity a prenos zodpovednosti za prospievanie mesta na jeho vedenie. Aj podl'a zástancov druhého názoru sa vzt’ah štátu a miest približne od osemdesiatych rokov 20. storočia mení v závislosti na zmenách ekonomických (kríza sociálneho štátu, globalizácia produkcie a spotreby a lokalizácia produkcie) a politických (moc nadnárodných inštitúcií kombinovaná s presunom regulačných zodpovedností na regióny a mestá) (Kazepov 2005). Avšak dosial' ostávajúci vplyv štátu rozhodne nie je zanedbatel'ný; Yuri Kazepov vyzdvihuje jeho dôležitost' pri určovaní inštitucionálneho (obmedzujúceho či naopak uvol’ňujúceho) kontextu, v ktorom mestské správy jednajú, a tým i stratégií, ktoré vyvíjajú. Iris Marion Young popisuje meniacu sa situáciu ako komplikovanejšiu - mestá síce získali väčšiu zodpovednost' za administratívu, ale často za cenu zníženia objemu administrovaných prostriedkov (Young 2003: 350). Presun určitých kompetencií a zodpovednosti zo štátu na mestá je preto sprevádzaný tlakom na mestské reprezentácie, aby jednali ako ekonomickí aktéri a snažili sa prelietavý kapitál potrebný pre vlastnú (a vlastnými silami zabezpečovanú) ekonomickú prosperitu prilákat', podobne, ako to robia národné štáty. Tie im ale zároveň stále stanovujú legislatívne obmedzenia. Závislost’ miest na štáte a širších administratívnych telesách sa nakoniec zvyšuje kvôli vznikajúcemu nedostatku financií na sociálne služby, ktorý sa vedenia miest snažia riešit' získavaním štátnej podpory (Young 2003: 349-350).

Strategické plány rozvoja mesta predstavuje Le Galès ako jeden z mechanizmov mobilizovania a prepojovania rozličných skupín v meste v tomto meniacom sa kontexte. Mesto, spolu s lokalitami a regiónmi, totiž bez ohl'adu na pretrvávajúcu a možno v určitých ohl'adoch prehlbujúcu sa závislost’ na štáte získava podobu zdroja a tvorcu lokálnej identity. Mestské plánovanie ponúkajúce obrazy harmonických miest, „,kde sa nezabúda na nikoho“ je tak popri sút’ažení s ostatnými mestami, boji proti chudobe, či kultúrnej mobilizácii, jednou zo stratégií regulácie a integrácie mestskej spoločnosti (Le Galès 2002: 214, 225). Le Galès dopín̆a svoje tvrdenie upozornením na určitú nejasnost' pojmov integrácia a integrovaná spoločnost', ktorú majú tvorit' obyvatelia mesta. Táto nejasnost' problematizuje tvrdenie, podl'a ktorého je spájanie sociálnych a politických skupín a záujmov v rámci mestského strategického plánovania znakom, že mesto ako úroveň integračných mechanizmov získava na význame (Le Galès 2002: 262-266).

K vymedzeniu významu spojenia stratégia sociálnej integrácie pre tento text a k ujasneniu vzt’ahu mestského plánovania k otázke integrácie napomáha článok Csabu Szaló Sociální inkluze a predpoklad kulturní zakotvenosti politické identity a jeho analýza myšlienky, podl'a ktorej je úspešná integrácia politicky vymedzenej komunity možná jedine v prípade, ak komunita zároveň zdiel'a jedinú kultúru. Autor zakladá svoju analýzu na kritickom čítaní 
Habermasovej teórie komunikatívnej akcie a sociológie práva. Historicky podmienený (rozhodne nie nevyhnutný) predpoklad stotožnenia príslušnosti k politickej komunite s príslušnost'ou ku komunite národa $\mathrm{v}$ národnom štáte vysvetl'uje ako stratégiu integrácie spoločnosti vyvinutú v čase jeho formovania: „Vznik národního státu můžeme považovat za úspěšnou institucionální strategii, která našla řešení problému legitimity právě prostř̌ednictvím nové formy sociální integrace“ (Szaló 2003: 38).

Problematika sociálnej integrácie je spojená s otázkou motivácie politického jednania sociálnych aktérov a legitimity autority politickej komunity. Ako píše Szaló, už od dôb stredoveku sú známe inštitucionálne stratégie riešenia problému legitimity a integrácie prostredníctvom politicky konštituovanej kultúrnej identity. „Tato institucionální strategie je založena na diskursivních praktikách pěstování identity jako př́slušnosti, výsledkem čehož je to, že subjekty nejenom vědí o tom, že patří do jisté politicko-kulturní komunity, ale emocionálně se s touto komunitou identifikuji““ (Szaló 2003: 38). V procese utvárania zdiel’anej identity hrajú významnú rolu procesy legitimizácie a diskurzívne reprezentácie, ktoré napomáhajú k pocitom solidarity a lojality príslušníkov politickej komunity (Szaló 2003: 43).

Stratégia integrácie a legitimizácie na úrovni národného štátu, predpokladajúca prepojenie inštitúcie občianstva a príslušnosti k národu a splývanie občianskej (politickej) a národnej (kultúrnej) identity, stráca podl’a Habermasa v podmienkach globalizácie moderných inštitúcií svoju účinnost' (Szaló 2003: 40). Patrick Le Galès popisuje reakcie súčasných európskych miest práve na tie zmeny, ktorých je oslabovanie národného štátu súčast'ou. Úloha národného štátu ako ochotného garanta prosperity miest a zároveň ako priameho určovatel'a ich rozvoja zrejme ustupuje. Mestá sa - okrem iného i prostredníctvom plánov rozvoja - vyrovnávajú s ekonomickou globalizáciou a zmenami, ktoré prináša európska integrácia.

Populácia miest je vymedzená administratívne, rovnako ako ich hranice. Takéto ohraničenie je obdobné vymedzeniu politickej komunity občanov štátu. Mestské plánovanie je komplexnou aktivitou, ktorá zahŕňa rozhodovanie o rozličných oblastiach „fungovania“ a podoby mesta. Je však tiež procesom tvorby reprezentácie mesta, plánom pre vytvorenie jedinečného image a identity mesta a jeho obyvatel'ov ako členov jednej komunity. Práve tento proces reprezentácie je súčast’ou stratégií integrácie, ako o nich pí̌e Le Galès. Plány ponúkajú obraz obyvatel'ov ako jednotnej spoločnosti a mesta ako jedinečného miesta, s ktorým je možné sa identifikovat'. $V$ čase oslabovania legitimity národného štátu a jeho integračných stratégií sa mesto ponúka ako alternatívna - alebo paralelná? - úroveň identifikácie. Dokumenty mestského plánovania by tým pádom mohli byt' považované za popis toho, do čoho sa obyvatel' mesta má integrovat', i spôsobu, ako by sa mal integrovat'. A práve preto je zaujímavé sústredit' sa na podobu zobrazenia tejto postavy i mestskej spoločnosti ako celku.

Ako ukazuje i stručný príklad brnianskej stratégie, v rámci mestského plánovania je okrem definovania obyvatel'a mesta popisovaná a cez tento popis konštruovaná odlišnost' skupín. Mestské plány popri definícii „obecného obyvatel’a mesta“, reprezentanta mestskej väčšiny, poskytujú i „definíciu druhého“ (other-definition Castlesa a Davidsona [2000]), ktorý je v meste podla plánovačov prítomný. Definícia i očakávania vztiahnuté k postave nositel’a inakosti nie sú formulované explicitne, ale vyjavujú sa prostredníctvom zobrazovania typov obyvatel’ov ako odlišných $\mathrm{v}$ jednotlivých častiach dokumentu. Hoci v prvej chvíli sa jednoduchým a základným návodom pre prináležanie ku skupine obyvatel'ov mesta Brna zdá byt' zdiel'anie vymenovaných 
potrieb, v súvislosti s otázkami bezpečnosti, kultúry či sociálnej starostlivosti prevládnu charakteristiky odlišnosti nad zdiel'aním základných potrieb a rozčlenia obyvatel’ov do oddelených kategórií, medzi ktorými sa zjavuje i príslušnost' k inému štátu či národu/národnosti.

\section{Integrovaná mestská spoločnost' ako alternatíva národného štátu?}

Nakol'ko je preto možné nad mestom uvažovat' ako nad alternatívnym zabezpečovatel’om „spoločenskej integrácie“, aký je vzt’ah mestskej a národno-štátnej integračnej stratégie? A ako tieto stratégie súvisia s tvorbou reprezentácií miest a obyvatel’ov v mestských plánoch? Súčasné mestské plánovanie je činnostou, ktorá prepája lokálnu správu s expertným urbanistickým plánovaním nadväzujúcim na tradície tejto disciplíny formovanej v 19. a 20. storočí. Plánovanie, ktoré je orientované na zmenu nielen fyzického, ale i sociálneho prostredia miest, kombinuje technické rozhodovanie s vytváraním predstáv priaznivého, vhodného a hodnotného života obyvatel’ov v mestách. V posledných desatročiach získavajú v západnej Európe, a po páde železnej opony i v post-socialistickej Českej republike, mestské plány špecifickú podobu komplexných strategických plánov rozvoja, utváraných ako podklad či súčast' plánov územných. Tieto dokumenty, podobne ako tie, ktoré urbanisti a plánovači vytvárali v predchádzajúcich obdobiach, zahŕňajú reprezentácie mesta a jeho užívatel’ov a pokúšajú sa reflektovat' a zohl'adňovat' rôznost' obyvatel'ov, ich potrieb i životných štýlov.

Upevňovanie a zlepšovanie image mesta a lokálnej identity je jedným z ciel’ov reprezentácií vyrovnávajúcich sa s novými úlohami, ktoré im ako správcom mesta pribúdajú v dôsledku meniacej sa úrovne štátnej garancie ekonomickej prosperity a roly štátu $\mathrm{v}$ určovaní ich rozvoja obecne. Túto zmenu, ktorá sprevádza problémy európskych sociálnych národných štátov, priniesli do vzt’ahu štátu a mesta posledné desat'ročia dvadsiateho storočia. Mestá sa v súčasnosti okrem iného zdajú byt' postavené pred úlohu „,integrovat"“ svojich obyvatel'ov a legitimizovat' lokálne rozhodovacie procesy aj poskytnutím na mesto viazanej identity. Vysporiadat's touto úlohou sa snažia i prostredníctvom mestských plánov ako podkladu či dokonca možného zdroja image mesta a seba-identifikácie obyvatel'ov. Proces vytvárania podobných integračných stratégií zahŕňajúcich obrazy (analýzy súčasného stavu i vízie budúcnosti) mesta a jeho administratívne vymedzenej spoločnosti sa tak do určitej miery podobá stratégii integrácie spoločnosti stotožňujúcej politickú a kultúrnu komunitu v národnom štáte, ktorá, zdá sa, stráca svoju účinnost'.

Odpovedat' na otázku, či preto môžeme nad mestom uvažovat' ako nad spoločenstvom, ktoré získava na význame $\mathrm{v}$ čase oslabovania národného štátu a poskytuje silnejúce alternatívne „úrovne občianskej identifikácie“, nie je až tak jednoduché. Napriek aktivitám a snahám miest vytvárat' strategické dokumenty či politiky integrácie a posilňovat' (či produkovat') výrazný lokálny image, sa prikláňam skôr k zápornej odpovedi. Ak sa totiž pozrieme na obraz mestskej spoločnosti, ktorý naznačuje dokument Strategie pro Brno, vidíme, že kategórie pôvodu v inom štáte či národnosti predchádzajú lokálnu príslušnost' obyvatel'a $\mathrm{k}$ mestu a potenciálne ho vyčleňujú z obrazu „bežného obyvatel'a“. Odlišné spôsoby zobrazovania skupín obyvatel'ov, ich „zakontextovanie“, ktoré ich odd'al'uje od „bežných občanov“, môžu totiž byt' práve následkom pretrvávania vnímania rozdielov medzi obyvatel’mi mesta na základe „štátnej“" príslušnosti a inakosti, ktorá do iných krajín situuje ich „,pôvod“. Ideál akejsi ,jednotnej“ mestskej spoločnosti, ktorá tieto rozdiely prekoná, neexistuje ani v samotných textoch, ktoré 
„ideálnu“ budúcnost' predstavujú. Ak prijmeme citované tvrdenia Françoise Choay, tak ho len t’ažko môžeme očakávat' $\mathrm{v}$ „skutočných“ priestoroch mesta. Plány rozvoja sú však pre náš text definované len ako záznam pohl'adu zvláštnej skupiny aktérov mestského života a ako ich hodnotovo podmienená reprezentácia mestskej spoločnosti. I preto by snaha odpovedat na danú otázku výlučne na základe práce s vybraným dokumentom popisujúcim plány rozvoja mesta Brna bola príliš ambiciózna. Každopádne si však môžeme dovolit' tvrdenie, že v tomto dokumente prítomné expertné prehovory o meste a jeho budúcnosti, rovnako ako aj zrejmé rozčlenenie obyvatel'ov, zachovávajú i v teoretikmi popísanom novom kontexte rozdelenia na bližšie a vzdialenejšie skupiny, ktoré vychádzajú z predstavy dôležitosti príslušnosti k národnému štátu, predčiacej príslušnosti lokálne.

\section{Pod'akovanie}

Za komentáre a pripomienky k textu d’akujem školitel’ovi Csabovi Szaló, Ph.D. a obom recenzentom Sociálních studií.

\section{Literatúra}

Balchin, P.; Sýkora, L.; Bull, G. (eds.) 1999. Regional Policy and Planning in Europe. London and New York: Routledge.

Campbell, S.; Fainstein, S. S. 2003. „Introduction: The Structure and Debates of Planning Theory." In S. Campbell, S. S. Fainstein (eds.) Readings in Planning Theory. 2nd Edition. Blackwell Publishing, s. 1-16.

Castles, S.; Davidson, A. 2000. Citizenship and Migration. London: Macmillan Press.

Choay, F. 1996. La règle et le modèle. Paris: Éditions du Seuil.

Choay, F. 1965. L'urbanisme, utopies et réalités. Paris: Éditions du Seuil.

Frisch, M. 2002. „Planning as heterosexist project.“ Journal of Planning Education and Research, 21: 254-266.

Hatziprokopiou, P. 2004. „Balkan Immigrants in the Greek City of Thessaloniki. Local Processes of Incorporation in an International Perspective." European Urban and Regional Studies, 11 (4): 321-338.

Häussermann, H. 1996. „From the Socialist to Capitalist City: Experiences from Germany.“ In G. Andrusz, M. Harloe, I. Szelenyi (eds.) Cities after Socialism: Urban and Regional Change and Conflict in Post-socialist Societies. Oxford: Blackwell, s. 219-231.

Kazepov, Y. 2005. „Cities of Europe: Changing Contexts, Local Arrangements and the Challenge to Social Cohesion." In Y. Kazepov (ed.) Cities of Europe: Changing Contexts, Local Arrangements and the Challenge to Social Cohesion. Blackwell, s. 3-42.

Koskela, H. 1999. Fear, Control and Space: Geographies of Gender, Fear of Violence, and Video Surveillance. Helsinki: Geography Institute at the University of Helsinki Publications.

Le Galès, P. 2002. European Cities: Social Conflicts and Governance. New York: Oxford University Press.

Mele, Ch. 2000. „The Materiality of Urban Discourse. Rational Planning in the Restructuring of the Early Twentieth Century Ghetto." Urban Affairs Review, Vol. 35, No. 5: 628-648.

Musil, J. 2002a. „Co se děje s českými městy dnes.“ In P. Horská, E. Maur, J. Musil Zrod velkoměsta: urbanizace českých zemí a Evropa. Praha: Paseka, s. 298-331. 
Musil, J. 2002b. „Urbanizace českých zemí a socialismus.“ In P. Horská, E. Maur, J. Musil Zrod velkoměsta: urbanizace českých zemí a Evropa. Praha: Paseka, s. 237-297.

Reynaud, T. A. J. 2004. „Migrants’ Accounts of Rio. The Contribution of Affect to Remembering Place." Space and Culture, 7 (1): 9-19.

Slovníkové heslo „Urban Planning“. In Wikipedia, the Free encyclopedia [on-line databáze]. HTML dokument [cit. 24. 9. 2006] dostupný z: http://en.wikipedia.org/wiki/Urban_planning

Szaló, C. 2003. „Sociální inkluze a předpoklad kulturní zakotvenosti politické identity občanství.“ Sociální studia, 9, MU Brno: 35-50.

Taylor, N. 1999. „Town Planning: ,Social“, not just ,Physical‘?“ In C. H. Greed (ed.) Social Town Planning. London a New York: Routledge, s. 29-43.

Taylor, N. 2003. Urban Planning Theory since 1945. London: SAGE.

Temelová, J. 2005. „High Profile Buildings: Help-mates in International and Local Competition. The Case of Prague." In F. Eckardt (ed.) Paths of Urban Transformation. Frankfurt am Main: Peter Lang. Europäischer Verlag der Wissenschaften, s. 81-96.

Thomas, J. M. 2003. „Educating Planners: Unified Diversity for Social Action.“ In S. Campbell, S. S. Fainstein (eds.) Readings in Planning Theory. 2nd Edition. Blackwell Publishing, s. 356-375.

Young, I. M. 2003. „City Life and Difference.“ In S. Campbell, S. S. Fainstein (eds.) Readings in Planning Theory. 2nd Edition. Blackwell Publishing, s. 336-355.

Zdroje

Strategie pro Brno. Strategický plán rozvoje města Brna. 2002. Manažer rozvoje města. Útvar hlavního architekta MMB.

\section{Autorka}

Slavomíra Ferenčuhová je doktorandka a odborná pracovníčka na Katedře sociologie Fakulty sociálních studií Masarykovy univerzity. V rokoch 2005 a 2006 bola odbornou pracovníčkou Institutu pro výzkum reprodukce a integrace společnosti FSS MU. Kontakt: ferencuh@fss.muni.cz 